\title{
PERFORMANCE OF SOLAR WATER HEATER WITH PRELIMINARY HEATING AT DIFFERENT WATER FLOW RATE
}

\author{
Mustafa $^{1}$, Sudarno ${ }^{2}$ \\ ${ }^{1}$ Lecturer, Mechanical Engineering, Merdeka University of Madiun, East Java, Indonesia \\ ${ }^{2}$ Lecturer, Mechanical Engineering, Merdeka University of Madiun, East Java, Indonesia
}

\begin{abstract}
The aim of this study is to develop the new model that can improve the efficiency of solar water heater. The research is conducted using the experimental method to improve the performance of solar water heater. It uses single-layer plate, double-layer plates and triple-layer plates of glass cover solar water heater. We investigate also some variations of intake flow rate that can improve the efficiency of model. The results are: 1) the best efficiency of the solar water heater uses triple-layer plates glass cover, if it is compared to the double layer plates and single layer plate of glass cover; 2) the efficiency value of solar water heaters increases linearly to the intake water flow rate. Generaly, the performance of double-wave absorber solar water heater using triple-layer plates of glass cover is better than double or single layer plates of glass cover.
\end{abstract}

Keywords: Absorber Plate, Intake Flow Rate, Double Wave, Solar Water Heater, Glass Cover

\section{INTRODUCTION}

According to Mustafa (2008), the efficiency of heat absorption in the solar heater double plates is higher than the efficiency of conventional heater solar heat absorption and heat absorption efficiency of the (Ti-Ta) / Gt in double plate solar heater decline more sharply than conventional solar heaters. Mustafa (2009), At each testing variation of the flow rate efficiency of heat absorption in the solar heater plate multiple higher than the efficiency of the heat absorption of solar heater conventional and temperature of the water out solar heater plate doubles in the afternoon decline more slowly than the temperature of the water out solar heater conventional, Ismail (2008), examines the absorber plate double and single use concrete absorbent on a simple solar water heater, solar water heater efficiency with simple double absorber plate is higher than the single absorber plate. Farid and Ismail (2010), concrete absorber plate waveform generating efficiency of solar water heater is higher than the flat absorber plate. According Anggraini (2001), using a thickness of $3 \mathrm{~mm}$ glass having an efficiency of solar water heater is higher compared to using glass thickness of $5 \mathrm{~mm}$ and the distance of the glass with the best absorber plate is $20 \mathrm{~mm}$. According to Mustafa and Ismail (2012), the best efficiency of solar water heater is the amount of three-layer cover glass compared to the amount of two-layer and one-layer glass cover, the greater the water flow rate, the efficiency of solar water heater increases, and with the initial wetness in the inlet water, causing the water temperature to come out and The absorbent plate temperature is relatively the same, so the efficiency of solar water heater close to zero.

From the research, it is necessary to do more research on the amount of cover glass on the solar water heater plate dual use glass with a thickness of $3 \mathrm{~mm}$ and the distance of the plate surface absorber with a glass cover by $20 \mathrm{~mm}$ to improve the performance of solar water heater, and also be carried out research on form absorber plate surface to improve the performance of solar water heater.

\section{LITERATURE REVIEW}

\subsection{Solar Water Heaters}

Solar water heating systems, can be broadly divided into three main parts:

1. Solar collector receiving and transferring the energy of solar radiation into thermal energy in the working fluid.

2. System working fluid channels or diverter pipe, the part that connects the collector to the storage.

3. The fluid storage tank that is part of the store and accommodate the hot water.

Based on the hot temperature desired major forms of thermal collectors can be broadly classified into three parts, namely:

1. Collectors type of concentration with low concentration of between $80^{\circ} \mathrm{C}-150 \mathrm{o} \mathrm{C}$.

2. The type of flat plate collectors for temperatures lower than $80^{\circ} \mathrm{C}$.

\subsection{Flat Plate Solar Collectors}

Solar water heaters generally consist of leaflets thermal conductive material called the absorber plate which connects the pipes carrying heat transfer fluid, usually water. Solar radiation transmitted through transparent pipes and converted into heat on the absorber plate and the bottom and sides isolated.

\subsection{Efficiency Flat Plate Collectors}

The efficiency of the collector panel is the ratio between the rate of useful heat (QU) is transferred to a fluid divided solar radiation on the cover plate. Efficiency can be shown in the 
equation of J.A. Duffie and Beckman W.A. (1980), as follows:

$$
\eta_{i}=\frac{Q_{u}}{A_{c} G_{t}}
$$

From the equation above can also use the collector efficiency equation below:

$$
\eta_{i}=F_{R}(\tau \alpha)-F_{R} U_{L} \frac{\left(T_{i}-T_{a}\right)}{G_{t}} \quad \eta_{i}=\frac{\dot{m} C_{P}\left(T_{\text {out }}-T_{\text {in }}\right)}{G_{t} \cdot A_{C}}
$$

Annotation:

$\mathrm{Q}_{\mathrm{u}}=$ The energy absorbed by the collector, $\left(\mathrm{W} / \mathrm{m}^{2}\right)$

$A_{c}=$ The area of the collector, $\left(\mathrm{m}^{2}\right)$

$\mathrm{F}_{\mathrm{R}}=$ Factors release of heat by the collector

$\mathrm{U}_{\mathrm{L}}=$ Overall heat losses $\left(\mathrm{W} / \mathrm{m}^{2}{ }^{0} \mathrm{C}\right)$

$\mathrm{G}_{\mathrm{t}}=$ Total solar radiation intensity $\left(\mathrm{W} / \mathrm{m}^{2}\right)$

$\mathrm{T}_{\mathrm{i}}=$ The temperature of incoming water $\left({ }^{0} \mathrm{C}\right)$

$\mathrm{T}_{\text {out }}=$ The temperature of the water out $\left({ }^{0} \mathrm{C}\right)$

$\tau=$ Transmissivity glass cover

$\alpha=$ Absorptivity absorber plate

\subsection{Preliminary Study}

Research solar water heater and absorber plates have been made by researchers. Some of them are used as a base to support the implementation of this study.

Bhide et al. (1982), introduced a simple method for comparing performance in which the thermal flat plate collectors is coated with a layer of a known value of absorption and reflection of sunlight. This is a simple way to get the value and appropriate for a particular election collector surface. This method shows the limits to the comparison layer to select a value and as well will benefit the total energy used in the selection of a good coating.

Rahmat (2001), conducted a research on the absorber plate for the distillation of sea water. From some of the test materials in this study, obtained copper material coated with black paint doff types have good heat absorption coefficient, which is 0.82 . In this study also made observations on the performance of solar still with a size of $1 \times 1 \mathrm{~m}$ with the addition of gravel on top of it on the plate absorber, the absorber plate shows the test results with the addition of gravel on top of it has a good efficiency.

Kris and San (2001), The parameters that affect the performance of the collector of which is the thickness of the absorber plate and the distance between the pipes collectors called fin efficiency of the collector. The results showed the thicker the absorber plate and the smaller the distance between the pipes collectors, the efficiency of the collector is getting optimum fin.

Anggraini (2001), this study was to determine the effect of the temperature within the glass kepelat large plate stating the heat received. The glass used for the research is clear glass and frosted glass with a thickness of each of $3 \mathrm{~mm}$ and $5 \mathrm{~mm}$. The result is that the highest temperature achieved when the glass plates used type of clear glass with a distance of $3 \mathrm{~mm}$ glass plate to $20 \mathrm{~mm}$.

Sambada (2004), circulation water from collector ketangki on solar heating termosifon iar occur naturally, due to differences in densities of water dikolektor with water in the tank so it does not require a pump, but performance may be better kerjanyanya of solar water heating systems which pump receipts. The study used a simulation chart $f$ that was used to estimate the performance of the heating system forced circulation water pump. The simulation results show that the number and area collectors, the number of daily hot water usage and the volume of water in the storage tank system affecting a large fraction of the solar water heater termosifon.

Rahardjo (2005), using two glass cover obtained a better efficiency compared to using only one glass. The temperature difference between the collector and the water out into the collector with 2 layers of the cover glass can be higher by about $17^{\circ} \mathrm{C}$ compared to collectors with a glass cover.

Ismail (2005), the flow rate of water in the solar heater, the faster the flow, the hot water produced at a temperature lower, and In solar water heaters type collector flat plate with an inclination angle of collector $0{ }^{\circ}$ produce the water temperature optimum is to average temperature of $59375^{\circ}$ $\mathrm{C}$ and a maximum temperature of $71^{\circ} \mathrm{C}$.

Farid dan Ismail (2006), The amount of three-layer cover glass with a thickness of $5 \mathrm{~mm}$ resulted in higher solar water heater efficiency compared to using two or one layer.

Mustafa (2006), the efficiency of heat absorption in the solar heater higher than the double plate heat absorption efficiency of conventional solar heaters and heat absorption efficiency of the (Ti-Ta) / Gt double plate solar heater decline more sharply than conventional solar heaters.

Ismail (2007), examined the flow rate of water in a simple solar heater using a single absorber plate, resulting in a faster rate of water flow produces lower performance of solar heaters, and vice versa.

Ismail (2008), examines the absorber plate double and single absorber using concrete cast in a simple solar water heater, solar water heater efficiency simple double-absorbing plate is higher than the single absorber plate.

Mustafa (2009), In each test variation of the flow rate of the efficiency of heat absorption in the solar heater plate multiple higher than the efficiency of heat absorption of solar heater conventional and temperature of the water out solar heater plate double on the afternoon of decline is slower than the temperature of the water out solar heater conventional. 
Farid and Ismail (2010), cast concrete absorber plate waveform generating efficiency of solar water heater is higher than the flat absorber plate.

\section{RESEARCH METHODS}

\subsection{Research Stages}

Based on background research on the innovation of solar water heater, this study originated from research that has been carried out, either by the lead researcher, member of the researchers as well as by other researchers. From the study, then do research to analyze the comparative form of a flat absorber plate surface with absorbent plate waveforms. The best results of the testing form absorber plate surface followed by analyzing the working fluid flow rate and final testing analysis of preheating the working fluid to see the maximum performance of solar water heater. At each stage of testing and sampling data, and then do the processing of data, graphed, analyzed and summarized.

\section{Research Equipment}

Research equipment using double plate collectors solar heaters, namely:

- Flat absorber plate of aluminum with a thickness of $3 \mathrm{~mm}$ and painted matte black.

- Wave absorber plates of aluminum with a thickness of 3 $\mathrm{mm}$ and painted matte black.

- Plate heat storage from PVC, $10 \mathrm{~mm}$ thick.

- Glass cover one side of $5 \mathrm{~mm}$ thick and north-facing orientation.

- The distance between the absorber plate and storage by 20 $\mathrm{mm}$

- Insulators of stereofoam material thickness of $3 \mathrm{~cm}$.

- Angle glass 150.

- The drains using PVC pipes of $25.4 \mathrm{~mm}$.

- Pump using an aquarium pump.

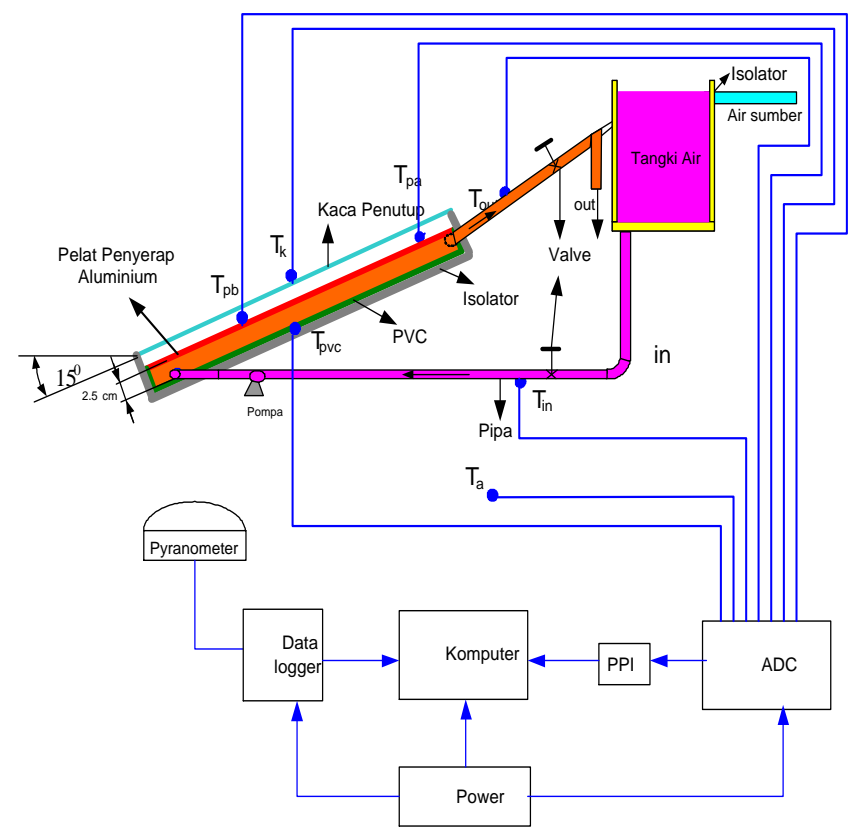

Fig-1: Schematic of solar water heater experiments (side view)

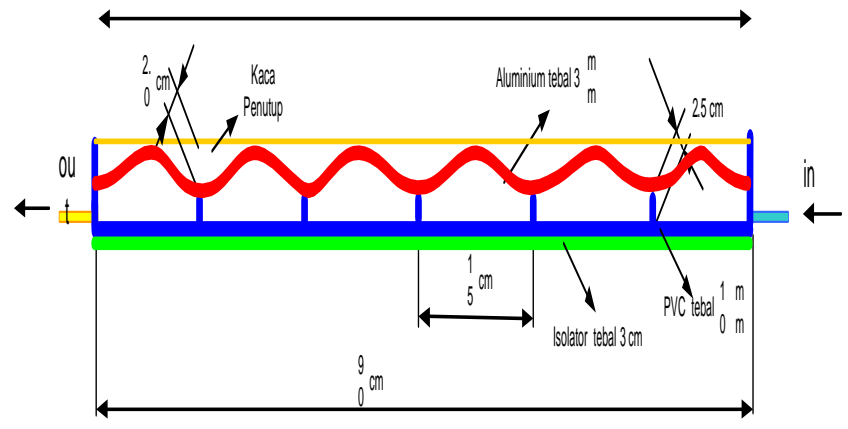

Fig-2: Schematic of wave absorbing experiments and zigzag plot (top view)

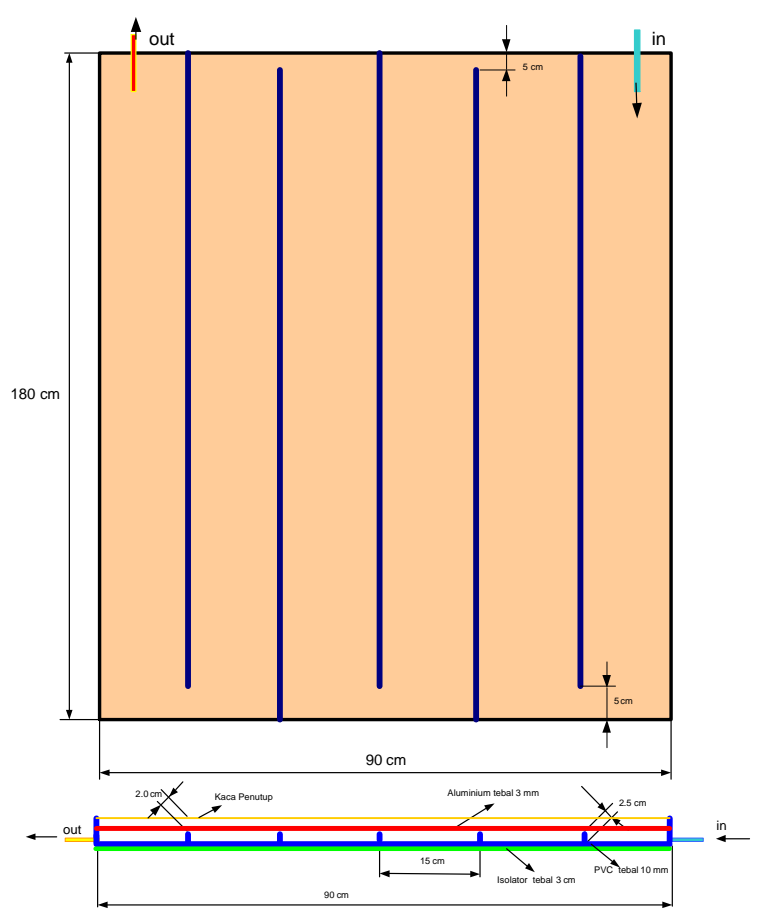

Fig-3: Schematic experiments of flat absorbent plate and zigzag groove (top view)

\section{Test Procedure}

Observations were made begin at $10.00 \mathrm{pm}$ until $14.00 \mathrm{pm}$ (peak time) directly under the sun with the duration of the recording of the data for every 10 minutes. Laboratory testing site in Department of Mechanical Engineering of Merdeka University.

\section{RESULTS AND DISCUSSION}

\subsection{Testing Surface Shape of Solar Radiation}

\section{Absorber Plate}

The data captured in the study testing the absorber plate surface shape on the solar heater comprises a double plate of the intensity of solar radiation, temperature of incoming water, temperature of the water out, the temperature of the absorber plate, cover glass temperature and ambient temperature. Data recording is done every 10 minutes to determine the time of data storage on DAI software. Furthermore, the data are calculated, graphed and analyzed. 


\subsubsection{The Temperature and the Intensity of Solar}

\section{Radiation Total Average}

From the test data can be graphed average temperature and total solar radiation intensity averages on test form absorber plate surface as follows:

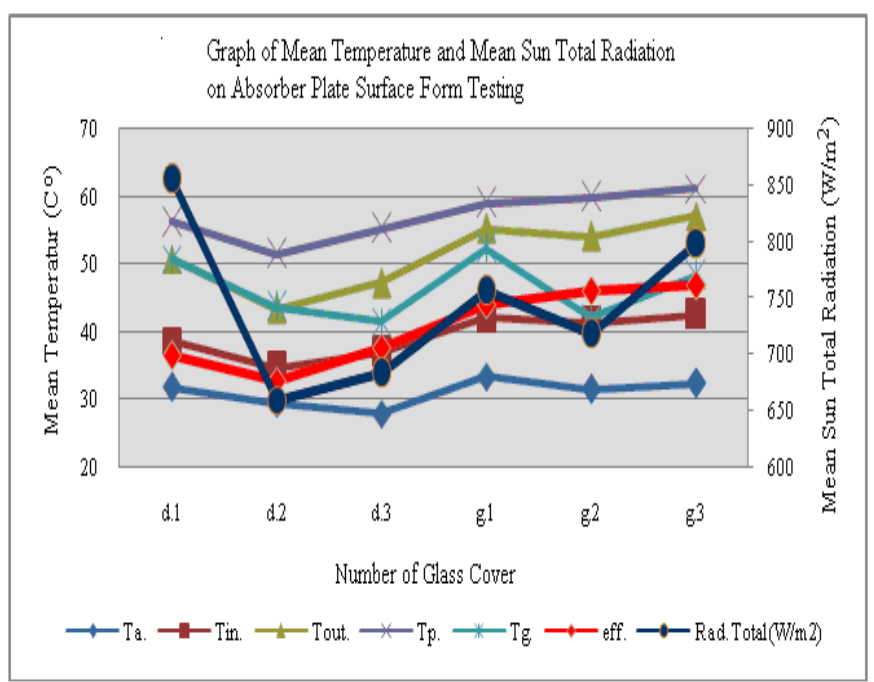

Fig-4: Graph of temperature and solar radiation intensity total average on testing form the absorber plate surface

\section{Annotation}

d.1 = Testing flat absorber plate first day

d.2 = Testing flat absorber plate second day

g.3 = Testing flat absorber plate third day

g.1 = Test day one wave absorber plate

g.2 = Testing second day surge absorber plate

g.3 = Test day three wave absorber plate

Solar radiation recorded by a data logger via pyranometer during the test varies, so does the temperature of the glass cover, the absorber plate temperature, ambient temperature, temperature of incoming water temperature and water out. Data obtained from 10.00 am until 14.00 in total then averaged and the result can be seen in Figure 4. From the graph looks intensity of total solar radiation on average have the same pattern with the average temperature (the temperature of the cover glass, the temperature absorber plate, the temperature of incoming water temperature and the water out). Thus the amount of energy absorbed by the solar water heater will be in accordance with the energy source is solar radiation energy. For ambient temperatures not entirely solar radiation pattern, it is because there are other factors that affect the temperature, the wind speed and air humidity.

\subsubsection{The Efficiency of the Heat Absorption of Solar}

\section{Radiation on the Surface Shape Testing Solar}

\section{Radiation Absorber Plate}

From the results of the study then calculate the double plate solar water heater using equation Kreith, 1982, 56 and
Duffie, 1980, 252. And the results of these calculations can create a graph of solar water heater efficiency to the (Ti-Ta) / Gt. as follows:

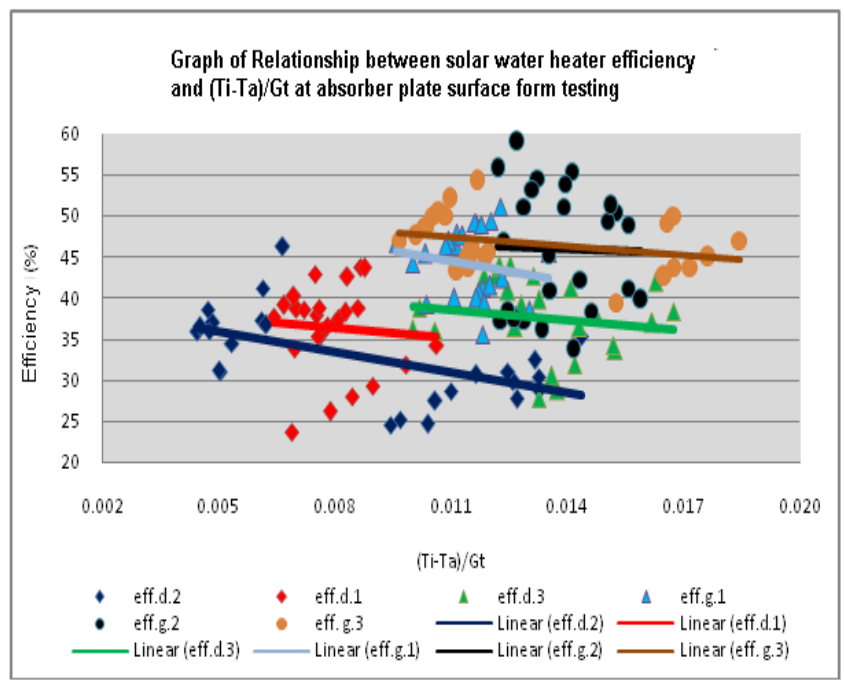

Fig-5: Graph relation efficiency solar water heater on the $\mathrm{Ti}-\mathrm{Ta} / \mathrm{Gt}$ on testing form a double absorber plate surface wave model

From the graph above it can be seen the efficiency of solar water heater with a double plate absorber plate surface can generate waveforms solar water heater efficiency is higher and more gentle decline in efficiency compared with the efficiency of solar water heater with flat plate surface absorbent form. These conditions are caused by a different surface area, so that the heat energy of solar radiation that is absorbed is greater. Thus the wave-shaped absorber plate surface can increase the efficiency of solar water heater.

\subsection{Flow Rate Testing using Absorber Plates Wave}

\section{Model}

From the test results form the absorber plate surface are best used absorbent surface wave-shaped plates are used in testing the water flow rate. From the data obtained will then be calculated, and the results can be graphed.

\subsubsection{The Temperature and the Intensity of Solar}

\section{Radiation on Average Total Flow Rate Testing}

From the test data can be graphed the average temperature and the intensity of total solar radiation on average on testing the water flow rate, as follows: 


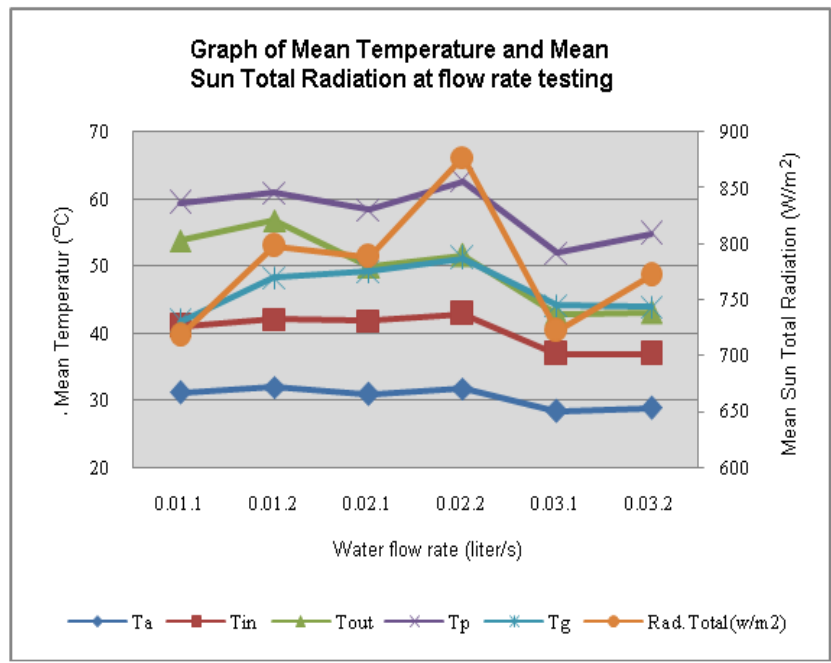

Fig-6: The graph of temperature and solar radiation intensity on the average total flow rate testing using a solar water heater double plate wave model

\section{Annotation \\ 0.01.1 $=$ Tests using 0:01 flow rate (liters/s) day 1 $0.01 .2=$ Tests using 0:01 flow rate (liters/s) day 2 $0.02 .1=$ Tests using 0:02 flow rate (liters/s) day 1 $0.02 .2=$ Tests using 0:02 flow rate (liters/s) day 2 0.03.1 = Tests using 0:03 flow rate (liters/s) day 1 0.03.2 = Tests using 0:03 flow rate (liters/s) day 2}

Solar radiation recorded by a data logger via pyranometer during the test varies, so does the temperature of the glass cover, the absorber plate temperature, ambient temperature, temperature of incoming water temperature and water out. Data obtained from 10.00 am until 14.00 in total then averaged and the result can be seen in Figure 6. From the graph looks intensity of total solar radiation on average have the same pattern with the average temperature (the temperature of the cover glass, the temperature absorber plate, ambient temperature, temperature of incoming water temperature and the water out). Thus the amount of energy absorbed by the solar water heater will be in accordance with the energy source is solar radiation energy. The decline in average temperatures is more visible in the test flow rate of 0:03 liters/s compared to the rate of water flow underneath.

\subsubsection{Efficiency of Solar Water Heater on the}

\section{Water Flow Rate Testing using a Solar Water Heater with Three Double Plate Glass Cover}

From the results of the experiment, we performed double plate heater calculation using Kreith, 1982, 56 and Duffie, 1980,252 , and the results can be seen in the following graph:

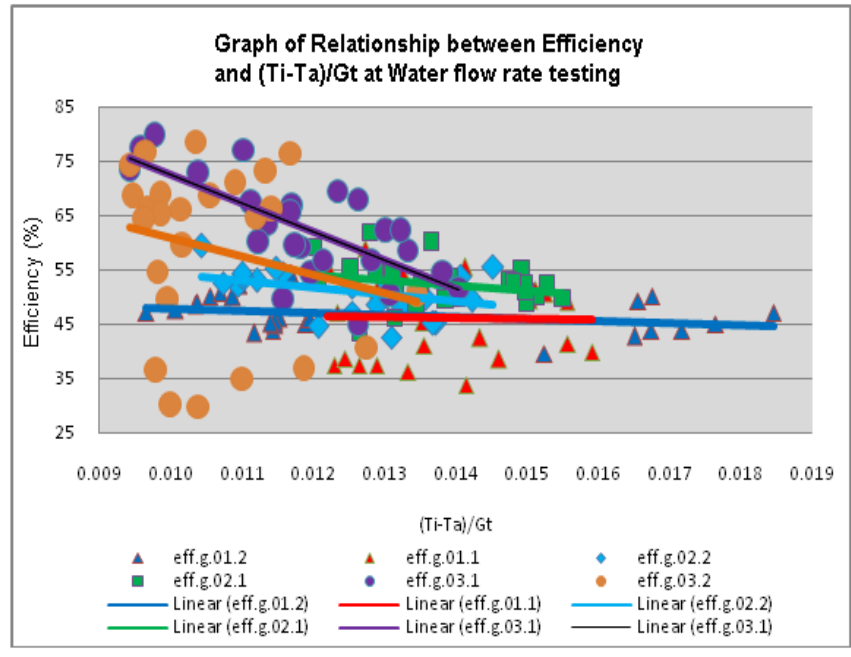

Fig-7: Graph relation efficiency solar water heater on the Ti-Ta / Gt at a flow rate testing using a solar water heater double plate wave model

From the graph it can be seen the efficiency of solar water heater plates double the flow rate of 0:03 ltr / s using the plate surface absorber wave-shaped to produce high efficiency solar water heater is higher and decreased efficiency sharper than the efficiency of solar water heater with a water flow rate 0:01 ltr / s and 0:02 1 tr / s. These conditions caused the flow rate itself, in which the flow rate in the calculation process as a multiplier, so the efficiency of solar water heater is higher, but the decline in the efficiency of the solar water heater (Ti-Ta) / Gt sharper.

\section{Discussion}

From the test form absorber plate surface can be seen a wave-shaped absorber plate surface has a larger surface area that absorbs heat in solar radiation absorber plate compared to a flat shape, so as to improve the efficiency of solar water heater.From the test results of water flow rate, the greater the flow rate of water up to 0.03 liters / s, the efficiency of solar water heater increases. These conditions are caused by the equation, where the rate of water flow is used as a multiplier, so the efficiency of solar water heater increases.

\section{CONCLUSION}

From the research results can be summarized as follows:

1. Efficiency Solar Water Heater is best wave-shaped absorber plate surface compared to the absorber plate surface is flat.

2. The greater the flow rate of water, then the efficiency of solar water heater increases.

\section{REFERENCES}

[1]. Arismunandar. W (1995), Teknologi Rekayasa Surya, PT. Pradnya Paramita.

[2]. Anggaraini E. H. (2001), Pengaruh jarak kaca ke pelat terhadap panas yang diterima suatu kolektor surya pelat datar, Jurnal Teknik Mesin, Universitas Kristen Petra. [3]. Bhide V. G. et. al, (1982),, Choice of selective coating for flat collector, solar energy, Vol. 29, No.6, pp. 463-465. 
[4]. Duffie J.A. dan Beckman W.A. (1980), Solar Engineering Of Thermal Processes. New York : John Willey \& Sons.

[5]. Farid A. dan Ismail N.R (2006), Pengaruh jumlah kaca penutup dan volume air terhadap kinerja solar heater sederhana, PHK-A2. Teknik Mesin. Universitas Widyagama Malang.

[6]. Holman J.P. (1995), Perpindahan Kalor , Jakarta : Penerbit Erlangga.

[7]. Ismail N.R (2005), Kecepatan aliran air pada solar water heater, LPPM. Universitas Widyagama Malang.

[8]. Ismail N.R (2007), Pengaruh jenis pelat penyerap dan laju aliran terhadap kinerja solar heater sederhana, PHK-A2. Teknik Mesin. Universitas Widyagama Malang.

[9]. Ismail N.R (2008), Pengaruh pelat penyerap ganda dan tunggal menggunakan beton cor terhadap kinerja solar heater sederhana, LPPM. Teknik Mesin. Universitas Widyagama Malang.

[10]. Farid A. dan Ismail N.R (2010), Pengaruh pelat penyerap bentuk gelombang dan reflektor terhadap kinerja solar heater sederhana, PDM 2010 Teknik Mesin. Universitas Widyagama Malang.

[11]. Kreith F and Kreider. F. Jan. "Solar Heating And Cooling Active And Passive Desing”. New York : McGrawHill.

[12]. Mustafa (2008), Studi eksperimen perbandingan kolektor pelat ganda dan kolektor konvensional terhadap kinerja solar water heater. Thesis, Pascasarjana Unibraw Malang

[13]. Mustafa (2009), Pengaruh pelat ganda dan laju aliran air terhadap kinerja solar water heater, PDMDikti.

[14]. Rahardjo T. dan Ekadewi A.H., "Unjuk Kerja Pemanas Air Jenis Kolektor Surya Plat Datar dengan Satu dan Dua Kaca Penutup", Jurusan Teknik Mesin Universitas Kristen Petra

[15]. Sambada R.FA (2004), "Fraksi Surya Pemanas Air Surya Termosifon", Prosiding, Seminar Nasional, Pengembangan Riset dan Teknologi dibidang industri. Jurusan Teknik Mesin - Universitas Sanata Dharma Yogyakarta

[16]. Kristanto P. dan San Y.K., (2001), Pengaruh Tebal Pelat Dan Jarak Antar Pipa Terhadap Performansi Kolektor Surya Pelat Datar, Jurnal Teknik Mesin, Universitas Kristen Petra.

[17]. Rahmad Subarkah (2001), "Penelitian Absorber Solar Still Untuk Distilasi Air Laut", Skripsi, Malang: Jurusan Teknik Mesin FT Unibraw Malang

\section{BIOGRAPHIES}

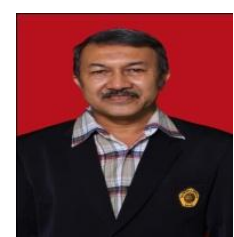

Lecturer at Merdeka University of Madiun.

Academic Background: Adhi Tama Institute Technologi of Surabaya, Brawijaya University of Malang

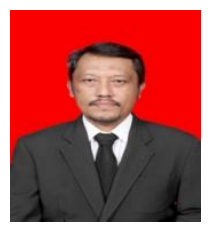

Lecturer at Merdeka University of Madiun.

Academic Background: Gadjah Mada University of Yogyakarta Sebelas Maret University of Surakarta 